\title{
Forest stand conditions after Phytophthora ramorum management in northern California: post-treatment observations inform future responses
}

\author{
Yana Valachovic ${ }^{1}$, Brendan Twieg ${ }^{1}$, Chris Lee ${ }^{2}$, Richard Cobb ${ }^{3}$, and Dan Stark ${ }^{1}$. ${ }^{1}$ University of \\ California Cooperative Extension, 5630 South Broadway, Eureka, CA; ${ }^{2}$ Cal Fire Humboldt-Del Norte Unit, \\ 118 S Fortuna Blvd, Fortuna CA; ${ }^{3}$ University of California at Davis, One Shields Ave, Davis CA. \\ Corresponding author: yvala@ucanr.edu
}

\begin{abstract}
In 2006, several isolated Phytophthora ramorum infested locations were selected just outside an 800-ha infested area in southern Humboldt County, California, for silvicultural treatments that targeted the removal and/or reduction of tanoak (Notholithocarpus densiflorus) and California bay laurel (Umbellularia californica), the main tree hosts supporting sporulation of P. ramorum. The treatments included cutting of hosts, cutting with burning, and herbicide removal. Important differences emerged between the treatment responses in shrub cover, tanoak resprouting, fuel loads, and host tree regeneration. In 2010, another isolated infestation was verified in northern Humboldt County. This infestation was 80 $\mathrm{km}$ away from the core infested area in southern Humboldt. Stand-level P. ramorum disease dynamic models and forest growth simulations parameterized with data collected in this northern infestation suggested that California bay laurel and tanoak thinning treatments may slow tanoak mortality, foster a greater component of mature tanoak over the next 100 years, and contribute to greater amounts of livetree carbon. Reviewing these long-running, landscape-scale $P$. ramorum management projects provides a platform to inform future adaptive management of $P$. ramorum. This paper summarizes two presentations from the Sixth Sudden Oak Death Science Symposium held in June 2016 in San Francisco, California.
\end{abstract}

\section{Introduction}

Phytophthora ramorum Werres, de Cock \& Man in't Veld, cause of sudden oak death (SOD), is suspected to have been introduced to the northern coast of California (Humboldt County; Figure 1) in the later 1990s (D. Rizzo personal communication). In 2002, the disease was discovered on California bay laurel (Umbellularia californica (Hook. \& Arn.) Nutt.) growing beneath old-growth coast redwood (Sequoia sempervirens (D. Don) Endl.) near Redway along the South Fork Eel River, approximately 29 $\mathrm{km}$ from the Pacific Ocean. Although symptoms were present, there was no observed tree mortality at the time. The pathogen subsequently spread through both redwood and Douglas-fir/tanoak (Pseudotsuga menziesii (Mirb.) Franco) / (Notholithocarpus densiflorus (Hook. \& Arn.) Manos, Cannon \& S. Oh) forests in southern Humboldt County. By 2008, P. ramorum-caused mortality of tanoak had reached at least 4,000 ha (Figure 1). Frequent late-winter precipitation combined with abundant host populations of dense tanoak and bay laurel trees occupying mid-story strata in both forest types likely fueled this rapid spread (Davidson et al. 2005, 2011).

Land managers, regulatory agencies, and private landowners identified the need for rapid response in an attempt to contain the pathogen. In 2004,with no previous $P$. ramorum wildland management experiments in California as a guide, initial management efforts attempted to contain pathogen spread through bay laurel removal in Redway neighborhoods, but results from subsequent surveys confirmed new $P$. ramorum positives outside this initial treatment area. These results challenged the feasibility of regionwide eradication. Because of this, management efforts in Humboldt County bifurcated: one effort focused on the invasion front with applied research to determine the best means of controlling the disease and 
reducing its impacts on individual properties, and the second focused on early detection monitoring to facilitate spot eradication of new infestations in otherwise uninvaded areas.

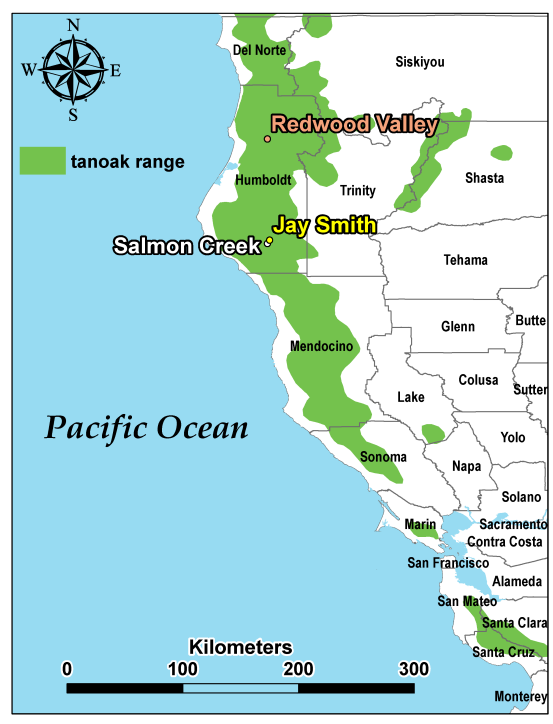

A

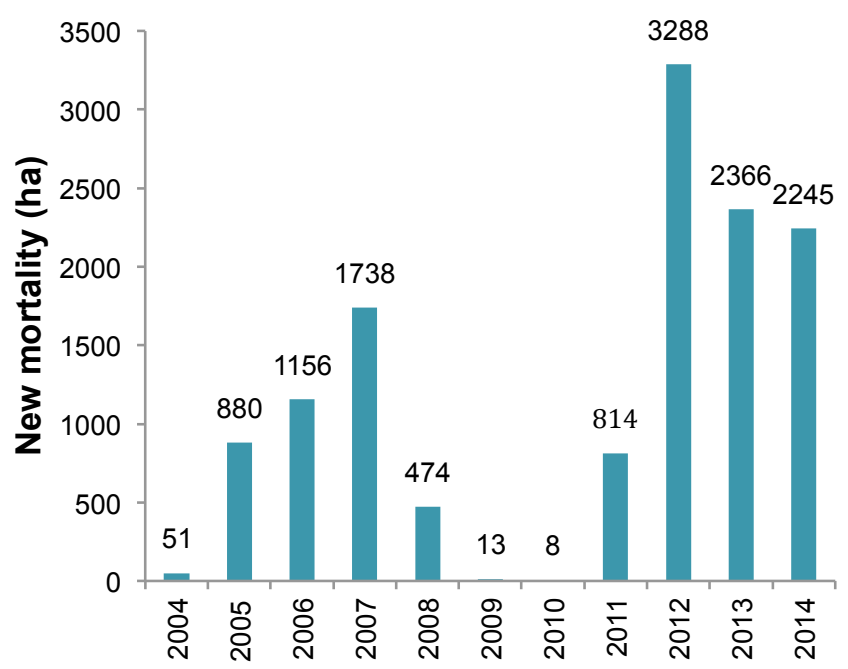

B

Figure 1. A) Locations of three study sites in Humboldt County, CA with reference to the range of tanoak. Jay Smith and Salmon Creek Sites are $\sim 3.4 \mathrm{~km}$ apart. B) Observed tanoak mortality in southern Humboldt recorded from USDA Forest Service aerial detection surveys that tallied a total 13,033 ha over ten years.

The first set of disease management activities in southern Humboldt County grew to encompass many experiments. The diversity of treatment approaches reflected differences in management goals and available tools. The results of three management efforts that sought to reduce pathogen populations at the invasion front are reported: (1) cutting all infested bay laurel and tanoak and a $30 \mathrm{~m}$ buffer using chainsaws and pile burning of the cut material; (2) removal of tanoak and bay laurel (as stated previously) followed by a prescribed fire to further sanitize the site; (3) herbicide application alone to remove the tanoak and bay and to prevent sprouting. Other case study treatments involved removal of bay laurel alone, thinning tanoak to prescribed densities, and use of phosphonates to protect tanoak groves in wildland settings (data not presented). Meanwhile, early detection efforts through stream monitoring led to the discovery of P. ramorum in northern Humboldt County wildlands in 2010, in the Redwood Creek watershed (Valachovic et al. 2013c). The new isolated find was over $80 \mathrm{~km}$ from the nearest known infected trees and was likely associated with human introduction of infested nursery stock (M. Garbelotto pers. comm.). This detection prompted localized host eradication attempts of tanoak and bay laurel, succeeded by efforts to slow pathogen spread and support regional tanoak survival through bay laurel removal on both private and public properties. These approaches to $P$. ramorum management evolved over the course of several years, adapting to new monitoring data and on-the-ground management constraints. For example, the Redwood Creek watershed projects expanded, in part by funding availability, to develop designs that could slow the spread into strategic areas (neighboring tribal lands and parks for example), to reduce wildfire potential to adjacent human communities, and to support longer-term carbon sequestration. Although our conclusions are supported primarily by experimental data, our discussion also includes our broader scale qualitative experiences with managing $P$. ramorum in these settings to inform future $P$. ramorum wildland management. This paper summarizes two presentations from the Sixth Sudden Oak Death Science Symposium held in June 2016 in San Francisco, California. 


\section{Methods}

\section{Southern Humboldt}

The sites selected for treatment in southern Humboldt County (Figure 1) in 2006 all feature similar precipitation, soils and forest types (Table 1). Prior to and following treatment, the sites were surveyed for forest stand and disease characteristics (Valachovic et al. 2013b) using fixed-radius 0.04-ha permanent plots; disease probability, estimated by logistical regression modelling, was about $65 \%$ for untreated plots and $30 \%$ for treated plots after 5 years of post-treatment monitoring, and disease frequency estimates throughout this period were similar between the sites (Valachovic et al. 2013b). The plots were randomly located and represented a 5 percent sample of the treatment areas. In 2016, a subset of permanent plots from two of the treatment areas, "Jay Smith" and "Salmon Creek," were re-measured for shrub cover and surface fuels. At Jay Smith, four untreated plots, eight plots treated by cutting of host trees plus subsequent prescribed pile-burn and broadcast burn, and eight plots treated only by cutting of host trees were measured. At Salmon Creek, five plots where hosts were treated by herbicide (imazapyr applied to standing trees with a "hack and squirt" method) and three untreated plots were measured. These plots were chosen from the permanent plots described in Valachovic et al. (2013b) by selecting one plot at random from each treatment unit and then selecting others to maximize the spatial spread of the plots within units.

Table 1. Comparison of site characteristics for study locations in Humboldt County, CA.

\begin{tabular}{|c|c|c|c|c|}
\hline Location & $\begin{array}{l}\text { Mean annual prec. } \\
(\mathrm{mm})^{1}\end{array}$ & $\begin{array}{l}\text { Soils (dominant soil series in } \\
\text { study areas) }\end{array}$ & Vegetation Type & $\begin{array}{l}\text { Appx. UTM } \\
\text { coordinates }^{2}\end{array}$ \\
\hline Jay Smith & 1551 & $\begin{array}{l}\text { Sproulish-Canoecreek- } \\
\text { Redwohly Complex; clay } \\
\text { loams, well-drained, high base } \\
\text { saturation }\end{array}$ & $\begin{array}{l}\text { Redwood grading } \\
\text { into Douglas- } \\
\text { fir/tanoak forest }\end{array}$ & $\begin{array}{l}\text { E } 429270 \\
\text { N } 4456783\end{array}$ \\
\hline Salmon Cr. & 1551 & $\begin{array}{l}\text { Sproulish-Canoecreek- } \\
\text { Redwohly Complex }\end{array}$ & $\begin{array}{l}\text { Douglas-fir/tanoak } \\
\text { forest }\end{array}$ & $\begin{array}{l}\text { E } 427624 \\
\text { N } 4453649\end{array}$ \\
\hline Redwood Cr. & 1783 & $\begin{array}{l}\text { Mooncreek-Noisy-Sidehill } \\
\text { Complex; gravelly clay loams, } \\
\text { well-drained, low to moderate } \\
\text { base saturation }\end{array}$ & $\begin{array}{l}\text { Douglas- } \\
\text { Douglasfir/tanoak } \\
\text { forest }\end{array}$ & $\begin{array}{l}\text { E } 427770 \\
\text { N } 4544508\end{array}$ \\
\hline
\end{tabular}

${ }^{1}$ Period of record: 2001-2016. Precipitation recording stations were located within 16-19 km of study areas. ${ }^{2}$ UTM Zone 10N. Datum: NAD83.

Fuel loadings were assessed using Brown's Transects (Woodall and Williams 2005). For these transects, three random azimuths were chosen per plot from plot center, spaced at least $30^{\circ}$ apart. Each transect was $10 \mathrm{~m}$ long and ran from 5 to $15 \mathrm{~m}$ from the plot center to avoid trampling of fuel beds during measurement. On each transect, 1-hr and 10-hr fuels were tallied between 5 and $7 \mathrm{~m} \mathrm{(6} \mathrm{m} \mathrm{total),} \mathrm{100-hr}$ fuels tallied between 5 and $10 \mathrm{~m}(15 \mathrm{~m}$ total $)$, and coarse woody debris ( $>7.6 \mathrm{~cm}$ diameter) measurements from 5-15 m (30 m total), with species, diameter, and decay class noted for each piece. Dead fuel bed height was measured at 5,6, and $7 \mathrm{~m}$, and litter and duff depth measurements were conducted at 5,10, and $15 \mathrm{~m}$ on each transect. Fuel loadings for coarse woody debris were estimated using species- and decay class-specific wood density values calculated from a dataset of measurements from northern California (Cobb et al. 2012a). Percent shrub cover was made by ocular estimate, and sapling counts by species were made on 0.02 -ha plots centered on the corresponding permanent plots.

Data from Jay Smith were analyzed with a set of linear or generalized linear models in the R statistical environment (R Development Core Team 2016) using cutting and fire as fixed effects; models with these effects were tested against alternative models with additional parameters (where applicable) and against the null model by Chi-square model comparison tests and evaluated for improvements in $\mathrm{R}^{2}$ values and by AICc (Burnham and Anderson 2002). Where generalized linear models were used, R package 
"piecewiseSEM" (Lefcheck 2015) was used to estimate $\mathrm{R}^{2}$. Shrub cover and tanoak stump sprout cover data were analyzed using generalized linear models with a Poisson distribution (using percent cover as a proxy for count data), with cutting and fire as effects; total shrub cover was tested as a predictor of tanoak stump sprout cover, along with the basal area of tanoak cut in the 2006 treatment. Where cutting or fire effects were detected for Jay Smith, data were re-analyzed by one-way analysis of variance with three separate treatments (cutting, cutting plus fire, no treatment) and a Tukey HSD test conducted to make pairwise comparisons. For comparisons of Salmon Creek untreated plots to herbicide-treated plots, Welch t-tests were used (2-sample t-test for groups with unequal variances).

\section{Northern Humboldt}

In 2013, a potential treatment area of 40-50 forested ha was identified on private land just beyond the eastern edge of the main body of the Redwood Valley P. ramorum infestation known at that time (Valachovic et.al. 2013c). This new treatment area included a ridge with slopes less than 35 percent suitable to mechanical treatment by a feller buncher. The treatment design included a "shaded fuel break" to thin ladder fuels and increase tree spacing to provide a control point for potential wildfires moving into or out of the wildland-urban interface and from the infested area. Since active disease management to control spread was underway throughout local infestations, precluding the possibility of leaving untreated plots within the treated area, our study here was not designed as a controlled experiment, but rather as a means of studying the impacts of treatment on stand structure and projecting modeled pathogen behavior within those altered stands. Our modelling exercise represents the predicted dynamics of the pathogen effects on stand-level conditions and carbon storage over 100 years.

In 2014, prior to treatment installation, a systematic grid of study locations was established across the area (90 $\mathrm{m}$ long transects spaced $120 \mathrm{~m}$ apart) at which to measure stand attributes both within and adjacent to the targeted treatment area. Pre-treatment evaluation of these locations included variable-radius forestry plots using a 20- or 30- basal area factor wedge prism, and trees less than $12.7 \mathrm{~cm}$ diameter at breast height (DBH) measured on 0.04-ha fixed-radius plots, in winter or spring 2014. The inventory included measurement of $\mathrm{DBH}$ and crown ratio for all trees in the variable radius plots, heights for one tree per each tree species in each variable radius plot, per each $12.7 \mathrm{~cm}$ DBH class, and counts of saplings $(<2.54$ to $<12.7 \mathrm{~cm} \mathrm{DBH}$ ) in the fixed radius plots (Twieg et al. 2017).

In $2014, \sim 16$ ha of the area was treated by cutting of all bay laurel and thinning of smaller and shorter tanoak from below the dominant crown positions to a residual spacing of $\sim 4.6$ by $4.6 \mathrm{~m}$. In patches where tanoak was not dominant, Douglas-fir was prioritized for cutting; spacing was achieved with cutting of only bay laurel, tanoak, and Douglas-fir. With intent to continue the same treatment throughout the remaining 24-34 ha, a stand-level sudden oak death dynamic model and the Forest Growth Simulator (FVS; Crookston and Dixon 2005) were used to forecast how the treatment would affect disease dynamics and forest structure over time and how this, in turn, would affect carbon storage (Twieg et al. 2017).

Both the SOD disease model and growth simulator were parameterized with the conditions measured in the stand yet to be treated. In the growth simulator, a thin-from-below treatment prioritizing cutting tanoak (or Douglas-fir secondarily as needed) to the final desired spacing was developed. We employed the SODDr model to forecast long-term disease dynamics and management efficacy (see Cobb et al. 2012 b; https://github.com/noamross/SODDr). Because bay laurel density can be highly variable, a secondary learning objective was to evaluate the effect of the relative importance for disease development of this sporulating host. Therefore, the SODDr model was also used to simulate a stand with $12.5 \%$ bay laurel stems rather than the true density of $2.5 \%$. 


\section{Results}

\section{Southern Humboldt}

The treatments resulted in differences in shrub cover, fuel loads, and host tree regeneration - both between treated and untreated units, and between burned and unburned cut treatments (see Valachovic $2013 \mathrm{a}$ and $2013 \mathrm{~b}$ for disease dynamics). The long-term effects following the cutting of tanoak and bay laurel host trees plus prescribed fire included some unexpected fire-related mortality in large diameter Douglas-fir trees at the Jay Smith site (data not shown, but in general mortality has averaged 1-2 large trees/year since treatment over a mortality center covering approximately $2.5 \mathrm{ha}$ ). At this site, redwood forests on the toeslope give way to drier Douglas-fir forests upslope with a substantial mid-story component of true oaks, indicating that the upper slopes may have been oak woodland in the past. Subsequent to treatment, we observed a variety of pathogens and insect pests infesting the Douglas-fir trees, including the root disease-causing fungi Phaeolus schweinitzii (Fries) Pat., Armillaria sp., and Leptographium wageneri (W.B. Kendr.) M.J. Wingf.; the aggressive buprestid beetle Phaenops drummondi (Kirby 1837); and the stress-responding bark beetles Dendroctonus pseudotsugae Hopkins, Scolytus unispinosus LeConte, and Pseudohylesinus nebulosus LeConte. Many of these pests are typically opportunistic and secondary (Furniss and Carolin 1977; Shaw and Kile 1991; Hessburg and Hansen 2000), indicating that post-treatment Douglas-fir mortality was related to pre-existing stress compounded by the prescribed fire and subsequent droughts. We observed that patches with mortality of large Douglas-fir resulted in larger openings with little or no tree canopy cover, and these patches were often dominated by shrubs, including blue blossom (Ceanothus thyrsiflorus Eschsch.) and poison-oak (Toxicodendron diversilobum (Torr. \& A. Gray) E. Greene).

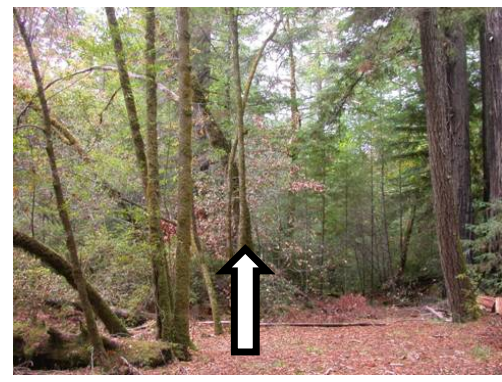

A

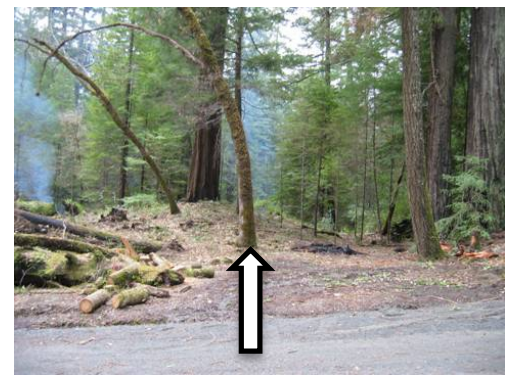

B

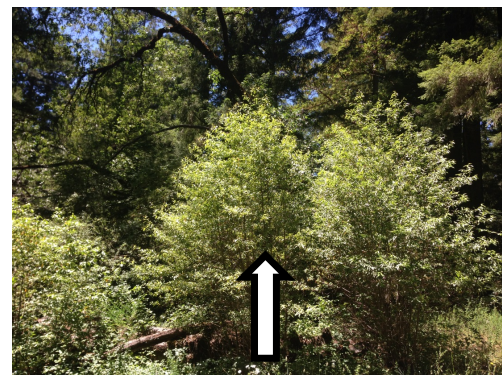

$\mathrm{C}$

Figure 2. A comparison of the same location pre-treatment (2006), immediately post-bay and tanoak removal (2007), and ten years after treatment (2016; resprouting bay laurel in foreground) at the Jay Smith site in Southern Humboldt. The arrow indicates the same tree through time.

Tanoak and bay laurel sprout response was ubiquitous as a result of the cutting treatment (Figure 2). Deer browse was not effective in controlling the basal sprouts, and ten years after treatment, tanoak sprouts had grown to over $2.5 \mathrm{~m}$ tall and bay sprouts were over $5 \mathrm{~m}$ tall, on average. Tanoak sprout cover at Jay Smith was positively related to basal area of tanoak cut in the treatment, but negatively related to fire (Figure 3); total shrub cover was not a significant predictor of basal sprouting. Where herbicides were applied at Salmon Creek, sprouting was largely absent. Only one plot had any sprouts emerging from the treated hosts and contributed $2 \%$ tanoak sprout cover. At Jay Smith, total shrub cover was not significantly affected by treatment (Figure 4). However, cover of blue blossom was significantly ( $<<0.0001$ for $\chi^{2}$ model difference test) higher in Jay Smith burned plots (mean $21.5 \% \pm 10.7 \%$ SE) than unburned plots $(0.5 \%$ mean $\pm 0.3 \% \mathrm{SE})$. Unburned plots instead had significantly higher cover of evergreen huckleberry (Vaccinium ovatum Pursh; $\mathrm{p}<0.0001$ for $\chi^{2}$ model difference test, $22.0 \%$ mean $\pm 10.4 \%$ SE) than burned plots $(3.8 \%$ mean $\pm 3.7 \% \mathrm{SE})$. 


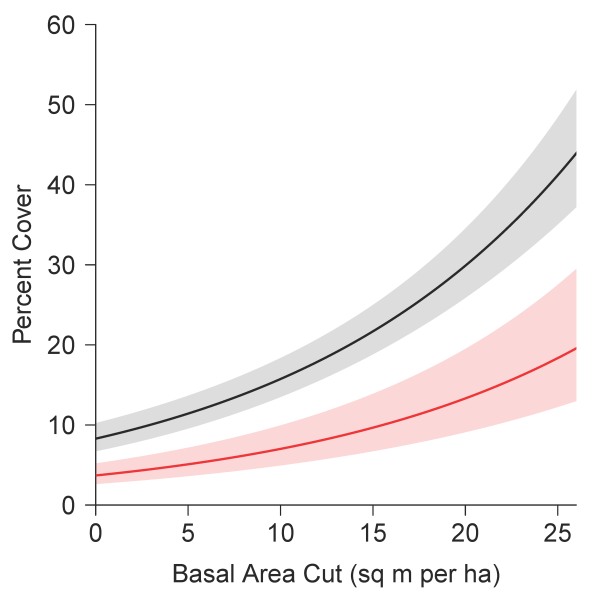

Figure 3. Model of cover of tanoak stump sprouts at Jay Smith in 2016 versus basal area of tanoak cut in 2006 without fire (black line) or with fire (red line). Shading represents $95 \%$ confidence of prediction; $R^{2}=0.52$.

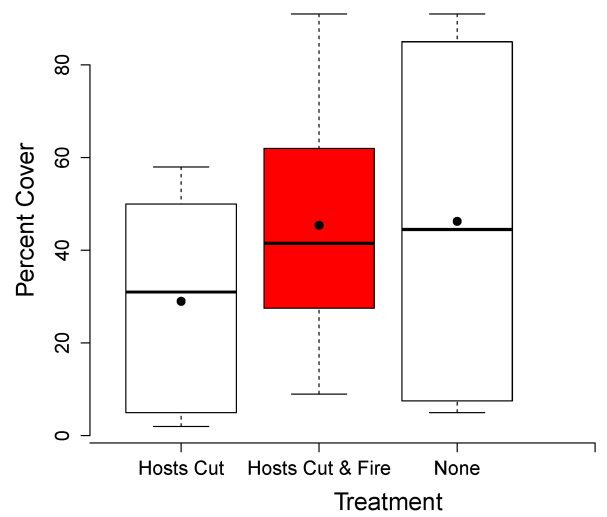

Figure 4. Total shrub cover in 2016 (10 years after treatment) at Jay Smith by treatmentboxplot with mean shown as dot.

Table 2. Comparison of duff and litter depth depths and fuel bed heights among treatments.

\begin{tabular}{lcccccc}
\hline Site-treatment & \multicolumn{2}{c}{ Duff Depth $\mathbf{( c m})$} & \multicolumn{2}{c}{ Litter Depth $(\mathbf{c m})$} & \multicolumn{2}{c}{ Fuel Bed Height (cm) } \\
\hline Jay Smith & Mean (SEM) & Plot Range & Mean (SEM) & Plot Range & Mean (SEM) & Plot Range \\
Cut only & $4.91(0.78) \mathrm{b}$ & $2.67-8.42$ & $3.29(0.56) \mathrm{ab}$ & $2.24-6.91$ & $9.96(1.19)$ & $3.17-12.82$ \\
Cut \& fire & $0.98(0.29) \mathrm{a}$ & $0.19-2.62$ & $1.54(0.26) \mathrm{a}$ & $0.72-2.59$ & $12.97(2.08)$ & $4.58-20.50$ \\
No treatment & $6.33(2.16) \mathrm{b}$ & $4.34-9.37$ & $4.24(0.98) \mathrm{b}$ & $1.89-6.34$ & $15.64(2.57)$ & $11.07-22.63$ \\
Salmon Creek & & & & & & \\
Herbicide & $2.81(0.56)$ & $0.17-4.02$ & $2.88(0.78)$ & $0.77-4.63$ & $16.97(4.32)$ & $8.43-30.20$ \\
No treatment & $3.74(1.03)$ & $1.98-5.57$ & $3.04(0.41)$ & $2.31-3.71$ & $8.76(2.48)$ & $6.09-13.72$ \\
\hline
\end{tabular}

Some effects on surface fuels were still detectable 10 years after treatment. While treated areas generally had higher amounts of coarse woody debris (i.e. $>7.6 \mathrm{~cm}$ diameter) from broadleaved tree species, the differences were not statistically significant (Figure 5). However, the herbicide treatment had $\sim 4 \mathrm{x}$ higher average loads of fine (i.e., $<7.6 \mathrm{~cm}$ diameter) woody debris than the untreated area at Salmon Creek (Figure $5 \mathrm{~d} ; \mathrm{p}=0.009$ ). The treatment at Jay Smith that involved the cutting of bay and tanoak and subsequent burning showed significantly shallower duff depths than both the cut-only treatment and untreated area, and it also had significantly thinner average litter layer than the untreated area (Table 2). With the addition of the prescribed burn, which resulted in some unintended tree mortality, fuel bed heights were slightly elevated over the cutting only treatment, but were still less than the control. For the herbicide treatment, where all material was left to decompose on the site, fuel bed depth was elevated respective to the untreated area, but concentrations of woody debris were patchy, and the difference between herbicide-treated and untreated areas was not statistically significant. 

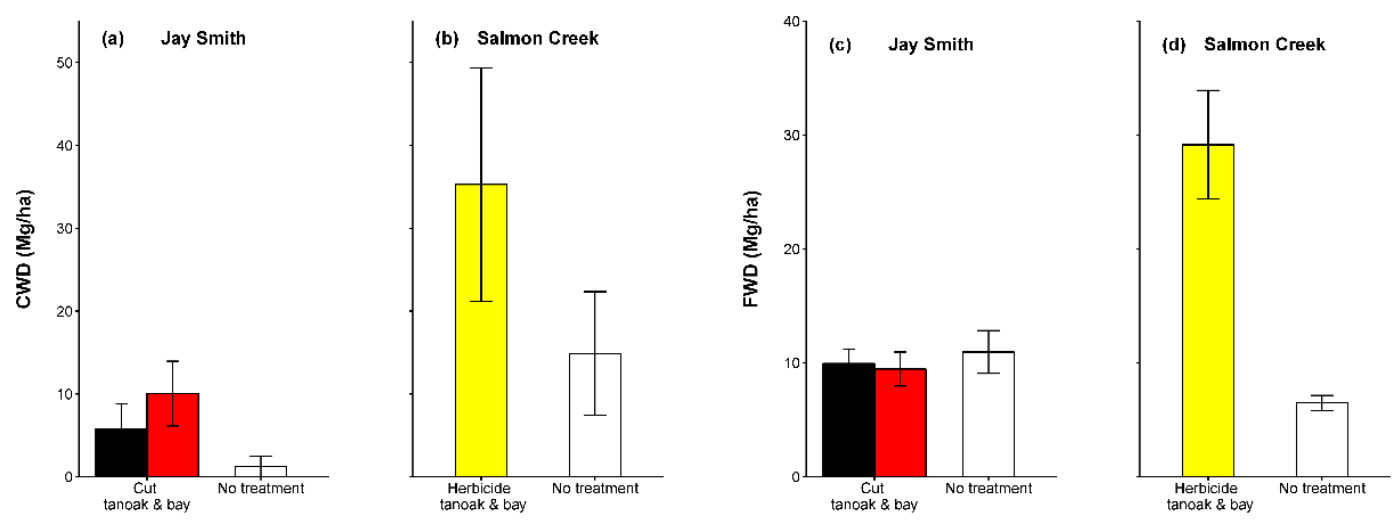

Figure 5. Mean coarse woody debris (CWD) loadings (broadleaf species only) by site and treatment (left panels) and mean fine woody debris (FWD) loadings (right panels; not differentiated by species). Error bars represent one standard error of the mean. Units are metric tons/hectare. Black bars are cutting only and red bars are cutting plus fire.

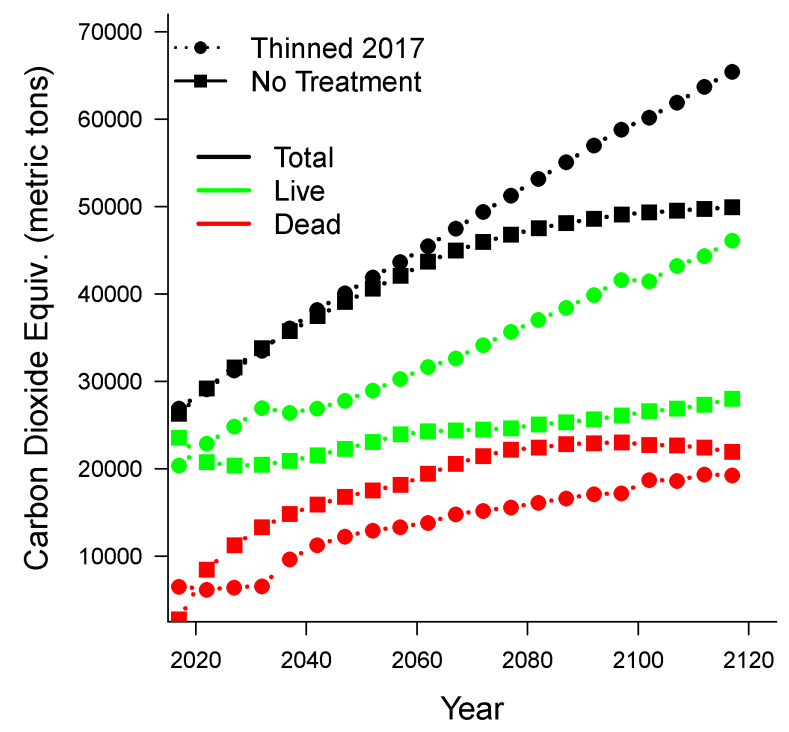

Figure 6. Stand stored carbon dioxide equivalents forecast under bay removed/tanoak thinned and untreated scenarios for 100 years of growth. Results correspond to (b) untreated and (c) thinned scenarios in Figure 7.

\section{Northern Humboldt}

Data from 14 of the combination of variable and fixed radius plot locations were used to model future disease dynamics and stand growth, representing the stand type that composed $\sim 21$ ha of the remaining area to be treated (depicted in Figure 7a). In all stand simulations (Figure 7b-d), stands in which bay laurel removal and tanoak thinning was simulated in 2017 were forecast to have higher basal area of tanoak remaining after 100 years of growth than untreated stands. As detailed in Twieg et al. (2017), the greatest forecasted treatment benefit for tanoak basal area retained in 2117 was under the scenario in which bay laurel is removed and tanoak is thinned, and mortality occurs in large tanoak first (Figure 7c). The carbon benefit was also highest in this scenario (Figure 6; other scenarios not shown here). With a hypothetical addition of $10 \%$ of bay laurel to the measured stand, in terms of stem proportions, higher 
mortality rates predicted by the SODDr model result in fewer tanoak trees forecast to be retained in the stand after 100 years (Figure 7d) than with the actual 2.5\% bay laurel component (Figure 7b).

Given that tanoak loss appears more dramatic in the stand depictions for simulations where mortality occurs in large trees first (see Twieg et al. 2017), the effects of having 10\% more bay laurel in the stand would look even more pronounced here if mortality was applied as such; in the simulation with the greater bay amount, mortality was instead specified to occur in all size classes equally. In comparison with scenarios in which mortality is applied uniformly among age classes and the stand is either (1) cleared of bay and the tanoak thinned or (2) untreated, the additional component of bay resulted in tanoak basal area being forecast in 2117 to be $58 \%$ lower than the stand with bay laurel removed and tanoak thinned, and $26 \%$ lower than the untreated stand with less bay laurel.

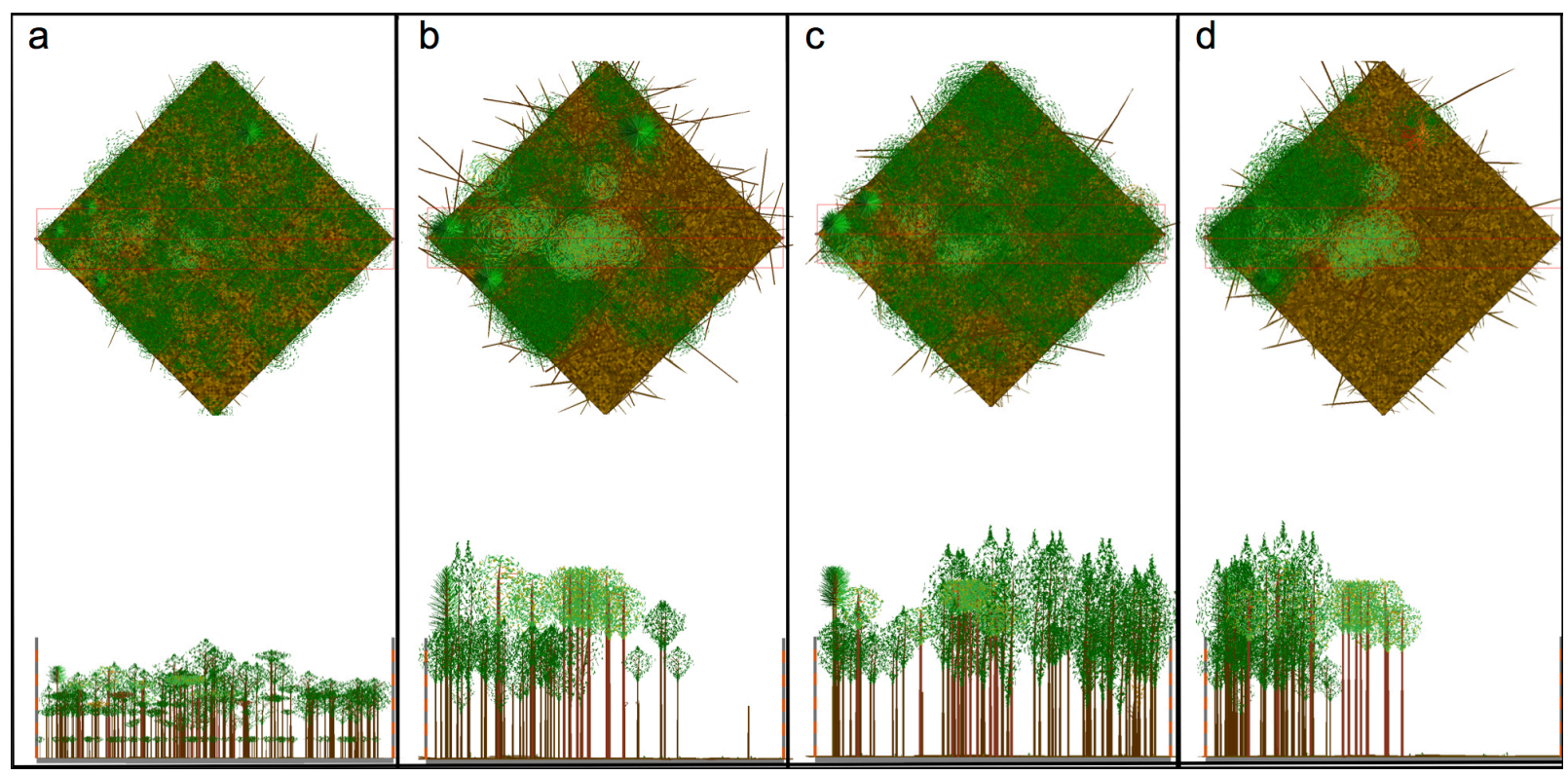

Figure 7. Stand representations from FVS stand visualization system for the (a) pre-treatment condition stand in 2017 and (b-d) growth simulated under three disease mortality scenarios until year 2117, from above (top) and in profile (bottom). In (b) the stand is untreated, and large trees are killed first by $P$. ramorum; in (c) bay laurel is removed from the stand and tanoak is thinned in 2017, with large trees killed first by $P$. ramorum; and in (d) disease dynamics are modeled with an additional $10 \%$ of the stand stems comprised by bay laurel and the stand goes untreated, but mortality is uniform across tree sizes at model initiation.

\section{Discussion}

Our 2016 results from both southern and northern Humboldt County management projects pertain specifically to the effects that $P$. ramorum management has on fuels accumulations, the effectiveness of herbicides in controlling resprouting host material, shrub regeneration stimulated by the creation of canopy openings, and potential tanoak/carbon retention over the long term. Effects of treatments on the pathogen itself and on bay and tanoak resprouts are addressed in Valachovic et al. (2013a, 2013b). These findings must be placed in the context of differing methodologies and levels of rigor between the two projects, as the southern study represents a controlled experiment, while the northern study relies on a parameterized model to forecast stand dynamics over the coming decades. The data presented here add to a growing body of knowledge collected over the course of the past ten years on the effectiveness of different types of treatments for controlling the spread of $P$. ramorum while concurrently achieving a 
variety of other forest management goals. We discuss data and model-driven results gained from a decade of observing the practicalities of management efforts in the north coast.

\section{Effects of treatments on stand}

Treatments to control the spread of $P$. ramorum can substantially change stand structure, function, and ecological services. The most obvious changes involve the resprouting host material. Sucker sprouts from host plants, both bay laurel and tanoak, are capable of being infected over time by inoculum from surrounding stands (Valachovic et al. 2013a). In California's north coast, bay laurel is especially effective in facilitating pathogen reinvasion and establishment following treatment. The eventual fate of infected tanoak sprouts and their attached root systems is unknown. Although socially controversial, herbicides are effective for solving the resprouting problem, as evidenced by the near-total lack of resprouting in plots treated by herbicide in this study.

P. ramorum treatments can also change the fuels profile of the stand: as shown in Table 2, treatments involving cutting reduced duff depths, litter depths, and fuel bed heights over those in the "no treatment" reference stands, while the addition of prescribed fire reduced litter and duff depths to an even greater degree when compared to untreated and cutting only. Herbicide treatment elevated fuel bed height, but this effect declined over time, and the fuel bed heights observed in this study were still lower than those observed in similar diseased or herbicide-treated stands in a previous study (Valachovic et al. 2011). Fuels management should be factored into P. ramorum treatment project design, and if addressed properly, it can result in an improvement in the overall fuels condition of a stand.

Data from the southern Humboldt treatment projects also support the important role of P. ramorum management in influencing subsequent shrub establishment and growth. Larger canopy openings were observed to provide a pathway to significant shrub response; although not captured or quantified by the study's sampling design, a sizable component of this shrub mid-story was observed to comprise nonnative species (e.g., Genista monspessulana (L.) L.A.S. Johnson) as well as natives Ceanothus thyrsiflorus and Toxicodendron diversilobum. Large canopy openings resulted from the unexpected deaths of individual Douglas-firs that were already stressed, suggesting the importance of assessing preexisting stand health before making treatment decisions. We observed that prescribed fires can interact with this canopy-opening dynamic, as they can stimulate seedbanks of non-native shrub species (DiTomaso et al. 2006). Some bay laurel trees were inadvertently left behind in the course of treatment: the fire did not kill these hosts, and several of them were found to be infected following treatment. Overall, this study shows that thinning and burning has forest health management utility that should be explored further even though it is not a cure-all for P. ramorum invasion (Valachovic et al. 2013a, 2013b).

New funding opportunities, such as the greenhouse gas funding administered by the California Department of Forestry and Fire Protection, provide another resource that may help us to better understand the stand-level effects of disease management or uncontrolled disease spread. Our findings indicate that treatments that achieve fire protection objectives and increase spacing in the forest also retain greater volumes of tanoak and larger tanoak trees well into the future, and achieving these goals comes with a benefit of lowered long-term $\mathrm{CO}_{2}$ emission. Even greater potential $\mathrm{CO}_{2}$ emission benefits are forecast when it is considered that similar treatments often reduce the likelihood that a wildfire will be of high severity in terms of tree mortality; this may be an even stronger consideration as the disease moves inland into tanoak stands that experience more summer drought than the stands examined here.

\section{Model performance}

There are some ways in which the models and simulations could be better optimized in future analyses. For example, the SODDr model was run assuming average stand conditions, uniformly distributed, across the modeled stand surface, but such homogeneity may not be common. It is possible that estimated 
cumulative mortality levels over a 100 -yr period would be affected by simplification of species distributions across the stand in the model, but it is unlikely that this effect would be significant at the limited spatial scale of the stand and relatively low bay laurel densities used in this study. Nonetheless, future models could improve on this assumption by incorporating stand heterogeneity. Other data are also needed to more accurately reflect tanoak growth and decay dynamics in FVS and other ecosystem-level applications (see Ehrenfeld 2010; Cobb et al. 2012a). A critical problem is that longer-term mortality dynamics of re-sprouting tanoak must be better understood and reflected in the FVS mortality parameters. Similarly, snag decay and fall dynamics of SOD-killed tanoak need to be better understood and models adjusted as necessary, since tree size and fall rates are a critical control on subsequent decomposition rates (Cobb et al. 2012a). Additionally, these trees often experience concurrent or subsequent infestation by insects that results in more rapid fall and decay (McPherson et al. 2010). The simulation results are in agreement with previous empirical and mathematical modeling of stand carbon changes under different initial stand conditions (Cobb et al. 2012b). Given that tanoak loss is more dramatic for stands where mortality is first seen in large trees, our results showed that increased bay laurel representation in the stand appreciably increased tanoak mortality and the associated impacts. Additionally management efforts that reduce inoculum will result in substantial benefits to stand-level carbon storage and lower fuels accumulations (Cobb et al. 2012a; Cobb et al. 2012b).

\section{Other observations and experiences concerning sudden oak death management}

Forest insect pest and disease management, especially management of non-native invasive species, is inherently complicated and challenging (for examples, see Anagnostakis 1997; Kinloch 2003; Dunstan et al. 2010; for discussion, see Gilligan 2008; Moser et al. 2009). The experiments we describe in this paper have yielded results not only in the form of empirical data and model-based forecasts, but also in the form of an extensive practical experience base; we provide a retrospective analysis here based on this experience to assess our past and future work in reducing the impacts of sudden oak death.

In the range of experiments that have been briefly discussed here, the land managers involved in these projects had to evaluate the merits of management or no management under the following uncertainties: 1) incomplete disease distribution information; 2) uncertainties about pathogen biology and spread;3) unpredictable weather conditions; 4) poorly defined management goals and objectives; 5) insufficient or unpredictable funding to accomplish objectives or to allow follow-up treatments; and 6) weak to nonexistent forest product markets to help offset the management costs. Furthermore, these managers had to accomplish permitting for the projects under stringent regulations that were not relaxed simply because of the forest health-oriented nature of the projects. As part of this permitting process, they had to abide by regulations regarding sensitive wildlife, archeological resources, and plant species, and commit to management decisions that sometimes lacked social acceptability to neighbors. Making land management decisions while burdened with imperfect information and limited time frames for response is common; applied scientific research is necessary to help inform these challenging choices.

After ten years of experience in P. ramorum wildland management in northern California, it is evident that landowners and managers struggle with defining their goals for managing this disease and sometimes develop unrealistically high expectations for a given project. None of the management experiments discussed here have featured the ability to conduct follow-up treatments to help mitigate unintended consequences, manage re-sprouting, or deal with other long-term challenges. Each of these projects has been dictated largely by a "get in and get out as quickly as possible" philosophy, with no fallback strategy should initial goals prove unachievable. Furthermore, project funders often have administrative constraints that impact specific project goals (e.g., pathogen eradication, complete control of the disease, or reduction of greenhouse gases) and are often unable to help with long-term project maintenance. Since 2006 these factors have increasingly fueled a developing social perception that successful disease management is unachievable. 
The projects presented here have resulted in a range of positive forest condition outcomes and suggested areas for improvement. While there is no perfect treatment combination for $P$. ramorum management, treatment should be designed to sufficiently address project goals. Two observations that consistently carry over from treatment to treatment, both in the north coast and in Oregon, relate to management scale and ability for early diagnosis. First, smaller infested areas will always be easier to treat than larger areas (Valachovic et al. 2013b). If containing substantial spread of $P$. ramorum is the land management goal, then treatments must be mobilized rapidly, before rainfall events encourage further spread. Second, cryptic infections are challenging to detect, and their presence can overwhelm treatment results. Tracking re-infection at Jay Smith and other sites adds to a convincing body of evidence that this is the case not only for large landscapes, but also for individual properties (Cobb et al. 2012b; Cunniffe et al. 2016). Even a few diseased but asymptomatic individual trees on the periphery of a treatment area can lead to relatively rapid reinvasion by P. ramorum (Kanaskie et al. 2010; Valachovic et al. 2013b).

As funding and the social appetite for disease management wane, what tools are appropriate? The answer depends on the project location, the neighboring stand conditions, and the resources at risk. Some land managers have moved from the goal of spot eradication or containment to protection of high conservation value stands (e.g. large diameter acorn-producing tanoak stands) and stands of cultural significance. Because of the long-distance spread potential of P. ramorum, the condition of adjacent properties puts pressure on most management approaches: a neighbor's decision not to manage diseased trees can overwhelm the success of an eradication strategy. However, this may not be as significant if the goal is to slow the spread and mitigate disease impacts. The question remains: where and when is eradication appropriate? A small percent of the California tanoak resource is actually infested, and as damaging as this disease has been, future impacts will likely be much greater. Additional concerns such as the potential for introduction of the EU1 strain strongly support the eradication strategy for isolated outbreaks and where landscape-scale cooperation among landowners is possible (Hansen et al. 2008; Valachovic et al. 2013c). However, eradication strategies will require a full management tool box and dedicated and sufficient resources. The success of an eradication strategy depends on a response and monitoring strategy that is rapid, thorough, and sustained over many years (Cunniffe et al. 2016).

\section{Conclusion}

After ten years of sudden oak death management, the most successful projects have integrated preexisting forest management goals with disease management. The ability to combine funding sources and goals has resulted in complementary outcomes such as improved roads, property access, and fuel reduction management, in addition to the forest disease objectives of reducing mortality and disease spread. Modeling, such as was used in the analysis of management impacts in northern Humboldt is a useful tool for making forecasts of project effects, but cannot be substituted for empirical-based evaluation. The inherent value of forest-level manipulations, such as those that were done in southern Humboldt is the ability for a comprehensive evaluation of treatment effects such as social acceptability through aesthetic evaluations, understory species response and weed species invasions, and interaction with actual weather conditions. This feedback between field experimentation and model development is critical for the improvement of both tools and for addressing the challenges posed by P. ramorum. While there have been a range of approaches taken in the projects discussed in this paper, continued experimentation is necessary to advance our understanding of $P$. ramorum disease dynamics and forest stand manipulations.

\section{Acknowledgements}

We thank the property owners for permission to conduct these experiments. California Department of Forestry and Fire Protection, California Department of Corrections, California State Parks, Institute for 
Sustainable Forestry, and Able Forestry were all very helpful in implementing these management experiments. Funding was provided by USDA Forest Service, Forest Health Protection, USDA Forest Service, Pacific Southwest Research Station, American Recovery and Reinvestment Act, and CAL FIRE Green House Gas Reduction Fund.

\section{Literature cited}

Anagnostakis, S. 1997. Chestnut blight: the classical problem of an introduced pathogen. Mycologia 79:23-37.

Burnham, K. P., and Anderson, D. R. 2002. Model Selection and Multimodel Inference: a Practical InformationTheoretic Approach. New York: Springer-Verlag.

Cobb, R. C., Chan, M. N., Meentemeyer, R. K., and Rizzo, D. M. 2012a. Common factors drive disease and coarse woody debris dynamics in forests impacted by sudden oak death. Ecosystems 15:242-255.

Cobb, R. C., Filipe, J. A. N., Meentemeyer, R. K., Gilligan, C. A., and Rizzo, D. M. 2012b. Ecosystem transformation by emerging infectious disease: loss of large tanoak from California forests. J. Ecol. 100:712-722.

Crookston, N. L, and Dixon, G. E. 2005. The forest vegetation simulator: a review of its structure, content, and applications. Computers and Electronics in Agriculture 49: 60-80.

Cunniffe, N. J., Cobb, R. C., Meentemeyer, R., Rizzo, D. M., and Gilligan, C. M. 2016. Modeling when, where, and how to manage a forest epidemic, motivated by sudden oak death in California. Proc. Natl. Acad. Sci. USA. 113:5640-5645.

Davidson, J. M., Patterson, H. A., Wickland, A. C., Fichtner, E. J., and Rizzo, D. M. 2011. Forest type influences transmission of Phytophthora ramorum in California oak woodlands. Phytopathology 101:492-501.

Davidson, J. M., Wickland, A. C., Patterson, H. A., Falk, K. R., and Rizzo, D. M. 2005. Transmission of Phytophthora ramorum in mixed-evergreen forest in California. Phytopathology 95:587-596.

DiTomaso, J. M., Brooks, M. L., Allen, E. B., Minnich, R., Rice, P. M., and Kyser, G. B. 2006. Control of invasive weeds with prescribed burning. Weed Technol. 20:535-548.

Dunstan, W. A., Rudman, T., Shearer, B. L., Moore, N. A., Paap, T., Calver, M. C., et al. 2010. Containment and spot eradication of a highly destructive, invasive plant pathogen (Phytophthora cinnamomi) in natural ecosystems. Biol. Invasions 12:913-925.

Ehrenfeld, J. G. 2010. Ecosystem consequences of biological invasions. Annu. Rev. Ecol. Evol. Syst. 41:59-80.

Furniss, R. L., and Carolin, V. M. 1977. Western Forest Insects. USDA Forest Service Miscellaneous Publication No. 1339. Washington, DC.

Gilligan, C. A. 2008. Sustainable agriculture and plant diseases: an epidemiological perspective. Philos. Trans. R. Soc. B. 363:741-759.

Hansen, E. M., Kanaskie, A., Prospero, S., McWilliams, M., Goheen, E. M., Osterbauer, N., Reeser, P. and Sutton, W. 2008. Epidemiology of Phytophthora ramorum in Oregon tanoak forests. Can. J. For. Res. 38:1133-1143.

Hessburg, P. F., and Hansen, E. M. 2000. Infection of Douglas-fir by Leptographium wageneri. Can. J. Bot. 78:1254-1261.

Kanaskie, A., Hansen, E., Goheen, E. M., Osterbauer, N., McWilliams, M., Laine, J., et al. 2010. Detection and eradication of Phytophthora ramorum from Oregon forests, 2001-2008. Pages 3-5 in: Proceedings of the Fourth Sudden Oak Death Science Symposium, Santa Cruz, CA. Frankel, S. J.; Kliejunas, J. T.; Palmieri, K. M., tech. coords. Gen. Tech. Rep. PSW-GTR-229. Albany, CA. Pacific Southwest Research Station, Forest Service, U.S. Department of Agriculture.

Kinloch, B. B., Jr. 2003. White pine blister rust in North America: past and prognosis. Phytopathology 93:10441047.

Lefcheck, J. S. 2015. piecewiseSEM: Piecewise structural equation modeling in R for ecology, evolution, and systematics. Methods Ecol. Evol. 7:573-579. 
McPherson, B. A., Mori, S. R., Wood, D. L., Kelly, M., Storer, A. J., Svihra, P., et al. 2010. Responses of oaks and tanoaks to the sudden oak death pathogen after $8 \mathrm{y}$ of monitoring in two coastal California forests. For. Ecol. Manag. 259:2248-2255.

Moser, W. K., Barnard, E. L., Billings, R. F., Crocker, S. J., Dix, M. E., Gray, A. N., et al. 2009. Inpacts of nonnative invasive species on US forests and recommendations for policy and management. J. For. 107:320-327.

R Development Core Team. 2016. R: a language and environment for statistical computing. Vienna, Austria. Available at: http://www.R-project.org.

Shaw, C. G. I., and Kile, G. A., eds. 1991. Armillaria Root Disease. USDA Forest Service, Agricultural Handbook No. 691. Washington, DC.

Twieg, B., Valachovic, Y., Cobb, R., and Stark, D. 2017. Reducing $\mathrm{CO}_{2}$ emissions by managing for sudden oak death . . . is it possible? Pages 19-22 in: Proceedings of the Sudden Oak Death Sixth Science Symposium. Frankel, S.J. and Harrell, K.M., tech. coords. Gen. Tech. Rep. PSW-GTR-255. Albany, CA: U.S. Department of Agriculture, Forest Service, Pacific Southwest Research Station.

Valachovic, Y., Lee, C., Marshall, J., and Scanlon, H. 2008. Wildland management of Phytophthora ramorum in northern California forests. Pages 305-312 in: Proceedings of the Sudden Oak Death Third Science Symposium, Santa Rosa, CA. Frankel, S. J.; Kliejunas, J. T.; Palmieri, K. M., tech. coords. Gen. Tech. Rep. PSW-GTR-214, Albany, CA. Pacific Southwest Research Station, Forest Service, U.S. Department of Agriculture.

Valachovic, Y., Lee, C. A., Scanlon, H., Varner, J. M., Glebocki, R., Graham, B. D. and Rizzo, D. M. 2011. Sudden oak-death caused changes to surface fuel loading and potential fire behavior in Douglas-fir-tanoak forests. For. Ecol. Manag. 261:1973-1986.

Valachovic, Y., Cobb, R., Rizzo, D., Twieg, B., Lee, C., Glebocki, R. 2013a. Is stump sprout treatment necessary to effectively control Phytophthora ramorum in California's wildlands? Pages 114-117 in: Proceedings of the Sudden Oak Death Fifth Science Symposium, Petaluma, CA. Frankel, S.J.; Kliejunas, J.T.; Palmieri, K.M.; Alexander, J.M. tech. coords. Gen. Tech. Rep. PSW-GTR-243. Albany, CA: Pacific Southwest Research Station, Forest Service, U.S. Department of Agriculture.

Valachovic, Y., Lee, C., Twieg, B., Rizzo, D., Cobb, R., and Glebocki, R. 2013b. Suppression of Phytophthora ramorum infestations through silvicultural treatment in California's north coast. Pages 108-113 in: Proceedings of the Sudden Oak Death Fifth Science Symposium, Petaluma, CA. Frankel, S.J.; Kliejunas, J.T.; Palmieri, K.M.; Alexander, J.M. tech. coords. Gen. Tech. Rep. PSW-GTR-243. Albany, CA. Pacific Southwest Research Station, Forest Service, U.S. Department of Agriculture.

Valachovic, Y., Quinn-Davidson, L., Lee, C., Goldsworthy, E., and Cannon, P. 2013c. Novel approaches to SOD management in California wildlands: a case study of "eradication" and collaboration in Redwood Valley. Pages 99107 in: Proceedings of the Sudden Oak Death Fifth Science Symposium, Petaluma, CA. Frankel, S.J.; Kliejunas, J.T.; Palmieri, K.M.; Alexander, J.M. tech. coords. Gen. Tech. Rep. PSW-GTR-243. Albany, CA. Pacific Southwest Research Station, Forest Service, U.S. Department of Agriculture.

Woodall, C., and Williams, M. S. 2005. Sampling protocol, estimation, and analysis procedures for the down woody materials indicator of the FIA program. Gen. Tech. Rep. NC-256. St. Paul, MN. North Central Research Station, Forest Service, U.S. Department of Agriculture. 